\title{
INFLUENCE OF DIFFERENT METHODS OF CROPPING AND WEED CONTROL ON THE CONTENT OF Cu AND Zn IN FODDER MAIZE (ZEA MAYS L.) AND ON THEIR UPTAKE BY MAIZE
}

\author{
Aleksandra Głowacka \\ Department of Soil and Plant Cultivation \\ University of Life Sciences in Lublin
}

\begin{abstract}
Strip intercropping is the practice of growing two or more species of plants in strips wide enough for independent mechanical cultivation, yet narrow enough to allow interaction between the species. This can affect not only crop yield but also competition in the uptake of nutrients and thus the chemical composition of the plants. The aim of this study was to assess the impact of strip intercropping and three methods of weed control on the content of zinc and copper in maize and on uptake of these components by maize. The study was conducted in 2004-2006 on a private farm located in the village of Frankamion$\mathrm{ka}$ in the administrative district (powiat) of Zamość. It was based on a field experiment conducted on clayey silt soil with grain-size distribution of clay and a moderate $\mathrm{Zn}$ and $\mathrm{Cu}$ content. The experiment design was a split-plot randomized complete block in four replications. The factors taken into account were two methods of cultivation: sole cropping and strip cropping (common bean, dent maize, and spring wheat in adjacent strips) and three methods of weed control: mechanical - weeding of interrows twice; mechanical-chemical the herbicide Gesaprim 90 WG $1.5 \mathrm{~kg} \mathrm{ha}^{-1}$ + weeding of interrows once; and chemical the herbicides Gesaprim 90 WG $1.5 \mathrm{~kg} \mathrm{ha}^{-1}+$ Milagro $040 \mathrm{SC} 1.5 \mathrm{~L} \mathrm{ha}^{-1}$. Fodder maize was grown for silage and harvested during milky-wax maturity. The content of copper and zinc in the dry matter of maize was determined by atomic absorption spectrophotometry (AAS) after digestion in $\mathrm{HNO}_{3}$ (extra pure) in accordance with PN-EN ISO 6869:2002. On average for the experiment, strip cropping of maize with common bean and spring wheat reduced zinc content in maize, but in successive years of the study, the impact of the cultivation methods was varied. Strip cropping significantly increased the copper content in the plants in comparison with sole cropping. $\mathrm{Zn}$ and $\mathrm{Cu}$ content varied depending on the location of a row in strip cropping.
\end{abstract}

Aleksandra Głowacka, PhD, Department of Soil and Plant Cultivation, University of Life Sciences in Lublin, Szczebrzeska 102, 22-400 Zamość, Poland, e-mail: aleksandra.glowacka@up.lublin.pl 
Location adjacent to a strip of beans was more favourable to zinc accumulation in the biomass of maize, while copper content was the highest in maize plants from rows adjacent to wheat, and lowest when grown next to a bean strip.

Strip cropping significantly decreased zinc uptake by maize, but the influence of cropping methods on copper uptake was not significant. The uptake of zinc and copper was the highest when the chemical weed control method was used, and resulted mainly from the high biomass of maize. The results confirm the impact of strip cropping on competition in the uptake of nutrients and on their content and total uptake.

Key words: maize, strip cropping, copper, zinc, content, uptake.

\title{
ZAWARTOŚĆ Cu I Zn W KUKURYDZY PASTEWNEJ (ZEA MAYS L.) ORAZ ICH POBRANIE Z PLONEM W ZALEŻNOŚCI OD METOD UPRAWY I REGULACJI ZACHWASZCZENIA
}

\begin{abstract}
Abstrakt
Uprawa współrzędna pasowa polega na uprawie dwóch lub więcej gatunków roślin w pasach wystarczająco szerokich, aby umożliwić niezależna mechaniczną uprawę, a jednocześnie dość wąskich, aby zachodziło ich wzajemne oddziaływanie. Może to wpływać nie tylko na plonowanie roślin, ale również konkurencję w pobieraniu składników pokarmowych, a co za tym idzie skład chemiczny roślin. Celem pracy była ocena wpływu współrzędnej uprawy pasowej i trzech metod regulacji zachwaszczenia na zawartość cynku i miedzi $\mathrm{w}$ kukurydzy oraz pobranie tych składników z plonem. Badania przeprowadzono w gospodarstwie indywidualnym położonym we wsi Frankamionka w powiecie zamojskim, w latach 2004-2006. Eksperyment polowy założono na glebie o składzie granulometrycznym pyłu ilastego, o średniej zasobności w $\mathrm{Zn}$ i Cu, metodą podbloków losowanych w układzie zależnym split-plot, w czterech powtórzeniach. Badanymi czynnikami były dwa sposoby uprawy: siew czysty i uprawa współrzędna pasowa (w sąsiadujących pasach fasola zwyczajna, kukurydza pastewna, pszenica jara) oraz trzy metody regulacji zachwaszczenia: mechaniczna dwukrotne opielanie międzyrzędzi; mechaniczno-chemiczna - herbicyd Gesaprim 90 WG $1,5 \mathrm{~kg} \mathrm{ha} \mathrm{ha}^{-1}+$ jednokrotne opielanie międzyrzędzi; chemiczna - herbicydy Gesaprim 90 WG $1,5 \mathrm{~kg} \mathrm{ha}^{-1}+$ Milagro 040 SC $1,5 \mathrm{l} \mathrm{ha}^{-1}$. Kukurydzę pastewna uprawiano na zielonkę i zbierano w fazie dojrzałości mleczno-woskowej. Zawartość miedzi i cynku w suchej masie kukurydzy oznaczono metoda absorpcyjnej spektrofotometrii atomowej (ASA) po mineralizacji w $\mathrm{HNO}_{3}$ (ekstra czystym) zgodnie z normą PN-EN ISO 6869:2002. Uprawa współrzędna pasowa kukurydzy z fasolą zwyczajna i pszenica jara średnio w doświadczeniu wpływała na zmniejszenie zawartości cynku w kukurydzy, jednak w kolejnych latach badań wpływ metod uprawy był zmienny. Uprawa współrzędna wpływała zaś istotnie na zwiększenie zawartości miedzi w roślinach $\mathrm{w}$ porównaniu $\mathrm{z}$ ich uprawą w siewie czystym. Zawartość $\mathrm{Zn} \mathrm{i} \mathrm{Cu}$ zmieniała się w zależności od położenia rzędu w uprawie pasowej. Sąsiedztwo z pasem fasoli sprzyjało gromadzeniu większej ilości cynku w biomasie kukurydzy, natomiast zawartość miedzi była najwyższa $\mathrm{w}$ roślinach $\mathrm{z}$ rzędów sasiadujących $\mathrm{z}$ pszenica, zaś najniższa w sassiedztwie pasa fasoli. Uprawa pasowa współrzędna wpływała istotnie na zmniejszenie pobrania cynku z plonem kukurydzy, zaś wpływ metod uprawy na pobranie miedzi nie był istotny. Pobranie cynku i miedzi z plonem roślin było największe w warunkach stosowania chemicznej metody regulacji zachwaszczenia i wynikało głównie z ilości biomasy kukurydzy. Uzyskane wyniki potwierdzają wpływ współrzędnej uprawy pasowej na konkurencję w pobieraniu składników pokarmowych oraz ich zawartość i pobranie z plonem.
\end{abstract}

Słowa kluczowe: kukurydza, współrzędna uprawa pasowa, miedź, cynk, zawartość, pobranie. 


\section{INTRODUCTION}

In recent years, maize has begun to play an important role in the Polish agriculture as animal feed, human food and raw material for industry (SzYMAŃSKA et al. 2009). It is a popular crop because it can produce high yield of both green matter and highly nutritional grain (BILSKI et al. 1997). The content of nutrients in maize depends on the plant development phase, cultivar-specific properties, soil richness and cultivation conditions (SzYszKowska et al. 2007, Simic et al. 2009, Skowrońska, Filipek 2009). Strip cropping involves growing two or more species of plants in strips wide enough to allow independent mechanical cultivation, yet narrow enough so that the species interact. This system not only affects crop yield, but also competition in the uptake of nutrients, with the power and direction of this competition depending on the nutrient and on the neighboring plants (GHAFFARZADEH et al. 1998, Li et al. 2001b, G£OWACKA 2010). Cultivated plants are a source of food for people and are used as animal feed in fresh or processed form. Therefore, their feeding value and proportions of their components are very important for the health of humans and animals (GRZYŚ 2004, GRAHAM et al. 2007). Copper and zinc are important nutrients in plants. Zinc is a component of many enzymes and is involved in the metabolism of carbohydrates, proteins and phosphorus compounds (AllowaY 2004, GoNDEK 2010). It participates in the synthesis of auxins and increases plant tolerance to drought and disease (Kabata-Pendias, Pendias 1999). It is also one of the most important elements conditioning the proper functioning of a human body (SALGUEIRO et al. 2000). It is a micronutrient that regulates protein metabolism (SzLEGEL-ZAWADZKA 2001) and - together with copper, boron, and manganese - has a significant effect on the carbohydrate metabolism (AlAALAOUI-Sosse et al. 2004). Copper is an activator of many enzymes involved in nitrogen metabolism and a conveyor of electrons in various biochemical reactions in plants. In the Polish literature, few studies have dealt with the impact of strip cropping on the yield of crop plants (BURCZYK 2003, G£owACKA 2008) and macronutrient uptake (GŁOWACKA 2010, GŁOWACKA et al. 2011). No information is available about the possible impact of strip cropping on the uptake of trace elements by crops.

The aim of this study was to assess the impact of strip cropping and sole cropping and of different methods of weed control on the content of copper and zinc in fodder maize and on their uptake by maize.

\section{MATERIAL AND METHODS}

The study was conducted in 2004-2006 as a field experiment on a private farm located in the village of Frankamionka in the administrative dis- 
trict (powiat) of Zamość. The field experiment was set up in a split-plot randomized block design in four replications. It was conducted on clayey silt soil with granulometric composition. The soil was slightly acidic $(\mathrm{pH}$ in 1 mol KCl 6.5) with $19 \mathrm{~g} \mathrm{~kg}^{-1}$ of organic matter and average content of available forms of zinc and copper (6.7-8.2 mg Zn kg${ }^{-1}$; 3.2-3.3 mg of $\mathrm{Cu} \mathrm{kg}^{-1}$ ).

The examined factors were as follows: I. method of cultivation, and II. weed control method. I. method of cultivation a) sole cropping, in which the size of plots was $23.75 \mathrm{~m}^{2}$ for sowing and $17 \mathrm{~m}^{2}$ for harvest, with 10 rows of maize spaced at $50 \mathrm{~cm}$ sown on each plot; b) strip cropping, in which three crops - common bean, fodder maize and spring wheat - were grown side by side in strips $2.5 \mathrm{~m}$ wide - five rows of maize were planted in each maize strip, spaced at $50 \mathrm{~cm}$. The size of maize plots was $11.75 \mathrm{~m}^{2}$ for sowing and $10.5 \mathrm{~m}^{2}$ for harvesting. II. weed control method: a) mechanical - weeding of interrows twice; b) mechanical-chemical - the herbicide Gesaprim 90 WG $1.5 \mathrm{~kg} \mathrm{ha}^{-1}$ (a.i. atrazine $135 \mathrm{~g} \mathrm{ha}^{-1}$ ) + weeding of interrows once; c) chemical - the herbicides Gesaprim 90 WG $1.5 \mathrm{~kg} \mathrm{ha}^{-1}$ (a.i. atrazine $135 \mathrm{~g} \mathrm{ha}^{-1}$ ) + Milagro 040 SC $1.5 \mathrm{~L} \mathrm{ha}^{-1}$ (a.i. nicosulfuron $60 \mathrm{~g} \mathrm{ha}^{-1}$ ).

The foder maize cultivar Veritis (FAO 230-240) was sown between $25^{\text {th }}$ April and $5^{\text {th }}$ May. Uniform mineral fertilization was applied consisting of $160 \mathrm{~kg} \mathrm{~N} \mathrm{ha}{ }^{-1}, 40 \mathrm{~kg} \mathrm{P} \mathrm{ha}^{-1}$ and $108 \mathrm{~kg} \mathrm{~K} \mathrm{ha}^{-1}$. Maize was harvested at the milky-wax stage (BBCH 79/83) in the second third of September. Spring wheat was harvested in the second third of August (BBCH 89), and beans in the third week of August or first week of September (BBCH 88/89). Detailed description of the experiment methodology is given in an earlier study (G£owACKA 2008). Meteorological conditions during the experiment were variable and are shown in Table 1.

Table 1

Rainfall and air temperature in April - September versus long-term means (1971-1988), according to the Meteorological Station in Zamość

\begin{tabular}{|c|c|c|c|c|c|c|c|}
\hline \multicolumn{8}{|c|}{ Rainfall (mm) } \\
\hline Years & Apr & May & June & July & Aug & Sep & $\Sigma$ Apr-Sep \\
\hline 2004 & 46.3 & 50.1 & 34.9 & 145.0 & 71.9 & 36.3 & 384.5 \\
\hline 2005 & 45.4 & 98.2 & 69.5 & 33.6 & 52.7 & 15.8 & 315.3 \\
\hline 2006 & 58.4 & 54.0 & 43.5 & 28.3 & 144.8 & 0.8 & 329.8 \\
\hline $\begin{array}{l}\text { Means for } \\
1971-2005\end{array}$ & 44.1 & 65.5 & 78.9 & 98.4 & 54.3 & 52.2 & 393.5 \\
\hline \multicolumn{8}{|c|}{ Temperature $\left({ }^{\circ} \mathrm{C}\right)$} \\
\hline 2004 & 9.6 & 13.5 & 18.1 & 19.4 & 19.7 & 14.3 & 2891 \\
\hline 2005 & 9.7 & 15.4 & 17.5 & 21.8 & 18.7 & 13.3 & 2948 \\
\hline 2006 & 10.5 & 14.8 & 18.4 & 23.3 & 19.0 & 16.8 & 3141 \\
\hline $\begin{array}{l}\text { Means for } \\
1971-2005\end{array}$ & 7.9 & 14.1 & 16.8 & 18.4 & 17.8 & 12.9 & 2690 \\
\hline
\end{tabular}


Every year prior to harvest, two plants were randomly collected from the middle rows of each plot. In addition, from each plot with strip cropping two plants were collected from the border rows adjacent to spring wheat and common bean and from the middle row. After the plants were crushed, dried, ground and wet mineralized in analytically pure $\mathrm{HNO}_{3}$, copper and zinc content was determined by atomic adsorption spectrophotometry (AAS) according to PN-EN ISO 6869:2002. The results were converted to dry weight. Analyses were performed at the Central Agroecological Laboratory of the University of Life Sciences in Lublin. Based on the content of the elements determined in maize and the yield volume (GŁowacka 2008), the uptake of zinc and copper was calculated. The results were analyzed statistically by analysis of variance (KALA 2009). Differences between means were assessed by Tukey's test. The significance of differences was determined with 95\% probability.

\section{RESULTS AND DISCUSSION}

Maize yields varied significantly in different years of the study (Table 2). Such substantial differences in yields may have resulted from weather conditions in different growing seasons. In 2005 and 2006, rainfall was much lower than in 2004 and the long-term average. Moreover, precipitation was very unevenly distributed in 2006 . In the first year, the yield of maize grown in sole cropping was significantly higher than in the strip cropping. However, on average for the whole period of the experiment, the cultivation method did not significantly affect maize yields. As might have been expected, of the three methods of weed control, the mechanical method had the least favourable effect on maize yield. The differences between the mechanicalchemical and chemical methods were within statistical error. In strip cropping, the yield from the border rows was only slightly higher than that obtained in sole cropping (GŁOWACKA 2008). Zinc content varied significantly as influenced by weather conditions during the study, methods of cultivation and weed control methods (Table 3). The zinc content in the biomass of maize ranged from 7.4 to $17.6 \mathrm{mg} \mathrm{kg}^{-1} \mathrm{~d}$.m. This can be regarded as low, as GorLACH and MAZUR (2002) state that zinc content in plants is $20-1,500 \mathrm{mg}$ $\mathrm{kg}^{-1}$ d.m. Studies by other authors have found that strip cropping increased total yield and allowed for more efficient use of nutrients (ZANGH, Li 2003). Li et al. (2001a) found that wheat was more competitive in the uptake of nutrients $(\mathrm{N}, \mathrm{P}, \mathrm{K})$ than maize or soy accompanying it in strip cropping. The present study also found that strip cropping affected the uptake of trace elements, but the change was not unidirectional, particularly with respect to zinc. On average for the experiment, maize grown in strip cropping with common bean and spring wheat contained slightly but significantly less zinc than in sole cropping. However, analysis of the particular years shows that 
Table 2

Yield of maize depending on the method of cropping and weed control ( $\left.\mathrm{Mg} \mathrm{d.m.} \mathrm{ha}{ }^{-1}\right)$

\begin{tabular}{|c|c|c|c|c|c|}
\hline \multirow{2}{*}{ Method of cultivation } & \multirow{2}{*}{$\begin{array}{c}\text { Weed } \\
\text { control* }^{*}\end{array}$} & \multicolumn{3}{|c|}{ Years } & \multirow{2}{*}{ Average } \\
\hline & & 2004 & 2005 & 2006 & \\
\hline Sole cropping & $\begin{array}{l}\mathrm{A} \\
\mathrm{B} \\
\mathrm{C}\end{array}$ & $\begin{array}{l}20.6 \\
22.9 \\
23.2\end{array}$ & $\begin{array}{l}14.6 \\
15.9 \\
18.7\end{array}$ & $\begin{array}{l}12.3 \\
16.7 \\
16.1\end{array}$ & $\begin{array}{l}15.8 \\
18.5 \\
19.3\end{array}$ \\
\hline Strip cropping - mean for plot & $\begin{array}{l}\text { A } \\
\text { B } \\
\text { C }\end{array}$ & $\begin{array}{l}18.8 \\
19.8 \\
20.9\end{array}$ & $\begin{array}{l}14.0 \\
17.9 \\
18.4\end{array}$ & $\begin{array}{l}11.6 \\
15.3 \\
15.2\end{array}$ & $\begin{array}{l}14.8 \\
17.7 \\
18.2\end{array}$ \\
\hline \multicolumn{2}{|l|}{$\operatorname{LSD}(\alpha=0.05)$} & n.s. & n.s. & n.s. & n.s. \\
\hline \multicolumn{6}{|c|}{ Average for factors } \\
\hline Sole cropping & - & $22.2^{b}$ & 16.4 & 15.4 & 17.9 \\
\hline Strip cropping - mean for plot & - & $19.9^{a}$ & 16.8 & 14.0 & 16.9 \\
\hline \multicolumn{2}{|l|}{$\operatorname{LSD}(\alpha=0.05)$} & 0.94 & n.s & n.s. & n.s. \\
\hline- & A & $19.7^{a}$ & $14.3^{a}$ & $11.9^{a}$ & $15.3^{a}$ \\
\hline- & $\mathrm{B}$ & $21.3^{b}$ & $16.2^{b}$ & $16.0^{b}$ & $18.1^{b}$ \\
\hline- & $\mathrm{C}$ & $22.0^{b}$ & $18.5^{c}$ & $15.7^{b}$ & $18.8^{b}$ \\
\hline \multicolumn{2}{|l|}{$\operatorname{LSD}(\alpha=0.05)$} & 1.45 & 1.81 & 3.05 & 1.59 \\
\hline Years & $\begin{array}{l}2004 \\
2005 \\
2006\end{array}$ & \multicolumn{4}{|c|}{$\begin{array}{l}21.0^{c} \\
16.6^{b} \\
14.5^{a}\end{array}$} \\
\hline \multicolumn{2}{|l|}{$\operatorname{LSD}(\alpha=0.05)$} & \multicolumn{4}{|c|}{1.65} \\
\hline
\end{tabular}

*Weed control: A - mechanical, B - mechanical-chemical, C - chemical

$a, b, c-$ mean in columns marked with the same letter do not differ significantly

strip cropping decreased the zinc content in maize only in the first year of the experiment. In the second year, higher zinc content was found in maize from strip cropping, while in the third year the cultivation methods did not produce a significant effect. This indicates strong influence of the weather on both yield-stimulating effect of strip cropping, as noted in other studies (Francis 1986), and on the chemical composition of plants in comparison with sole cropping.

In strip cropping, zinc content in maize varied depending on the row in a strip (Figure 1). On average, irrespective of the method of weed control, the highest zinc content was in the maize growing in the row adjacent to beans and the lowest - in the middle row. These results are consistent with the results of a study by G£OWACKA et al. (2011) on the impact of strip cropping on content and uptake of magnesium by maize. Analysis of the changes in zinc content in plants from different rows, including the method of weed control, shows that they were similar when the mechanical-chemical and 
Content of zinc in maize depending on the method of cropping and weed control ( $\mathrm{mg} \mathrm{kg}^{-1}$ d.w.)

\begin{tabular}{|c|c|c|c|c|c|}
\hline \multirow{2}{*}{ Method of cultivation } & \multirow{2}{*}{$\begin{array}{c}\text { Weed } \\
\text { control}^{*}\end{array}$} & \multicolumn{3}{|c|}{ Years } & \multirow{2}{*}{ Average } \\
\hline & & 2004 & 2005 & 2006 & \\
\hline Sole cropping & $\begin{array}{l}\text { A } \\
\text { B } \\
\text { C }\end{array}$ & $\begin{array}{l}15.1^{c} \\
17.6^{e} \\
12.5^{b}\end{array}$ & $\begin{array}{c}7.4^{a} \quad 9.0^{b} \\
12.6^{d}\end{array}$ & $\begin{array}{l}15.5^{c} \\
13.4^{a} \\
16.3^{d}\end{array}$ & $\begin{array}{l}12.7^{b} \\
13.3^{c} \\
13.8^{d}\end{array}$ \\
\hline Strip cropping - mean for plot & $\begin{array}{l}\mathrm{A} \\
\mathrm{B} \\
\mathrm{C}\end{array}$ & $\begin{array}{l}11.1^{a} \\
12.1^{b} \\
16.2^{d}\end{array}$ & $\begin{array}{l}10.9^{c} \\
11.5^{c} \\
11.3^{c}\end{array}$ & $\begin{array}{l}17.6^{e} \\
13.2^{a} \\
14.1^{b}\end{array}$ & $\begin{array}{l}13.2^{c} \\
12.2^{a} \\
13.8^{d}\end{array}$ \\
\hline $\operatorname{LSD}(\alpha=0.05)$ & & 0.81 & 0.95 & 0.71 & 0.28 \\
\hline \multicolumn{6}{|c|}{ Average for factors } \\
\hline Sole cropping & - & $15.1^{b}$ & $9.7^{a}$ & 15.0 & $13.24^{b}$ \\
\hline Strip cropping - mean for plot & - & $13.1^{a}$ & $11.2^{b}$ & 14.9 & $13.07^{a}$ \\
\hline \multicolumn{2}{|l|}{$\operatorname{LSD}(\alpha=0.05)$} & 0.29 & 0.34 & n.s. & 0.12 \\
\hline- & A & $13.1^{a}$ & $9.1^{a}$ & $16.5^{c}$ & $12.9^{a}$ \\
\hline- & $\mathrm{B}$ & $14.8^{c}$ & $10.2^{b}$ & $13.2^{a}$ & $12.8^{a}$ \\
\hline- & $\mathrm{C}$ & $14.3^{b}$ & $11.9^{c}$ & $15.2^{b}$ & $13.8^{b}$ \\
\hline \multicolumn{2}{|l|}{$\operatorname{LSD}(\alpha=0.05)$} & 0.44 & 0.52 & 0.39 & 0.25 \\
\hline Years & $\begin{array}{l}2004 \\
2005 \\
2006 \\
\end{array}$ & \multicolumn{4}{|c|}{$\begin{array}{l}14.1^{b} \\
10.4^{a} \\
15.0^{c}\end{array}$} \\
\hline \multicolumn{2}{|l|}{$\operatorname{LSD}(\alpha=0.05)$} & \multicolumn{4}{|c|}{0.25} \\
\hline
\end{tabular}

*Weed control: A - mechanical, B - mechanical-chemical, C - chemical $a, b, c$ - mean in columns marked with the same letter do not differ significantly

chemical methods were applied, but somewhat different in the case of the mechanical method (Figure 2).

The copper content in aerial plant organs is usually between 5 and 20 $\mathrm{mg} \mathrm{kg}^{-1} \mathrm{~d} . \mathrm{m}$. (Kabata-Pendias, Pendias 1999). Hence, the copper content in maize determined in this study can be said to be low but within this range. Strip cropping significantly increased the copper content in the maize compared to sole cropping (Table 4). The variations in the copper content in maize, depending on the row within a strip, were different than in the case of zinc. The copper content was lower in maize plants from the row adjacent to common bean strips than in the middle row or the row adjacent to spring wheat, with no significant differences between the two latter variants (Figure 3). It may have ben so because wheat was harvested earlier than beans and therefore stopped competing with maize for minerals. Similarly, GŁOWACKA et al. (2011) reported that strip cropping affects the calcium con- 


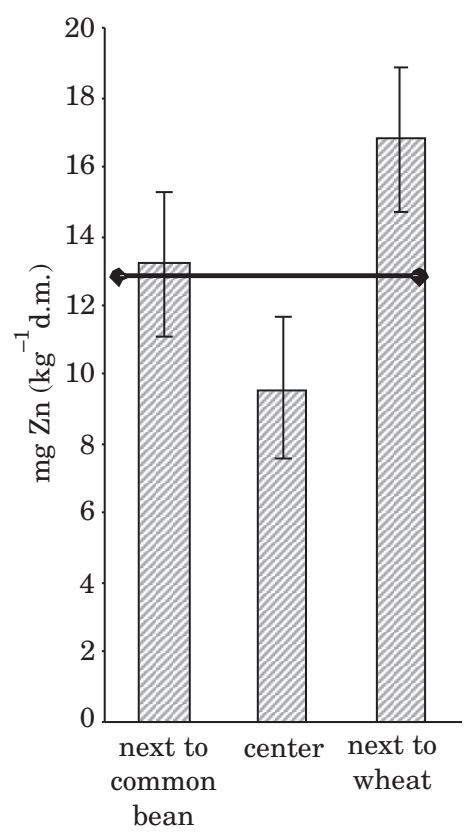

mechanical

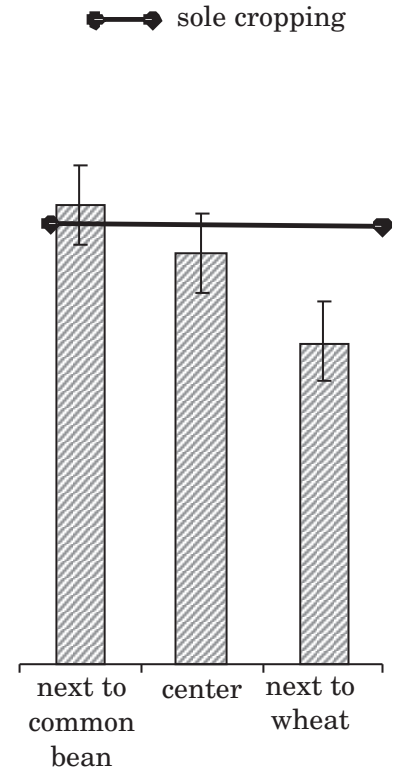

mechanical-chemical

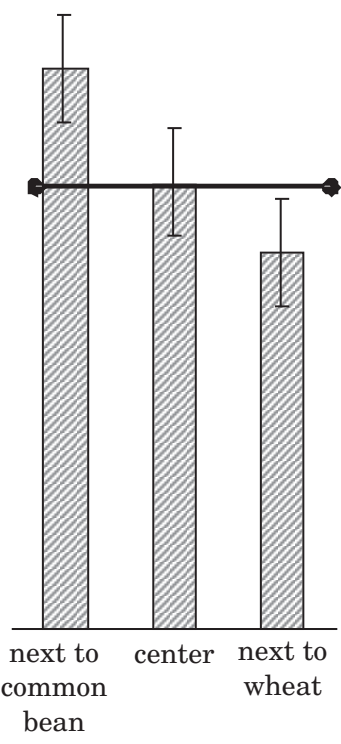

chemical

Fig. 1. The influence of adjacent row on zinc content in maize

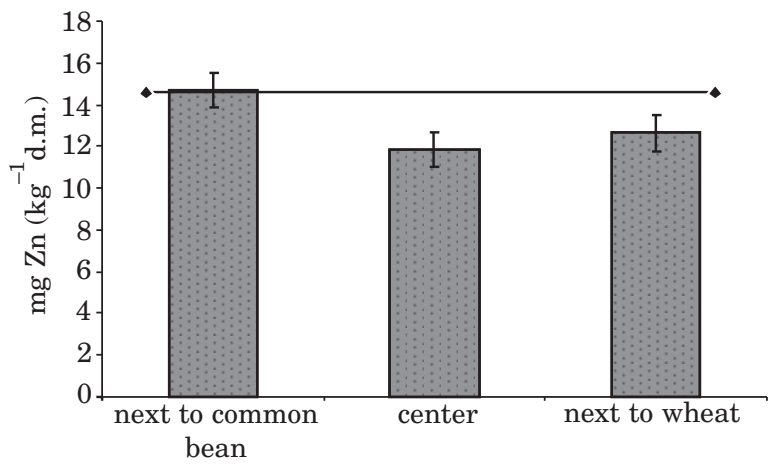

Fig. 2. The influence of adjacent row and weed control method on zinc content in maize

tent in plants. Maize growing in the row adjacent to the wheat strip contained more macronutrients than maize from the row adjacent to common bean. When Li et al. (2001b) studied the impact of strip cropping of maize and wheat on changes in the uptake of $\mathrm{N}, \mathrm{P}$ and $\mathrm{K}$, they found significantly lower uptake in the earlier stages of maize development and faster uptake in the later growth period (after the wheat harvest), as compared to sole cropping. As a result, at the stage of full maturity the content of these 
Table 4

Content of copper in maize depending on the method of cropping and weed control (mg kg-1 d.w.)

\begin{tabular}{|c|c|c|c|c|c|}
\hline \multirow{2}{*}{ Method of cultivation } & \multirow{2}{*}{$\begin{array}{c}\text { Weed } \\
\text { control* }^{*}\end{array}$} & \multicolumn{3}{|c|}{ Years } & \multirow{2}{*}{ Averag } \\
\hline & & 2004 & 2005 & 2006 & \\
\hline Sole cropping & $\begin{array}{l}\text { A } \\
\text { B } \\
\text { C }\end{array}$ & $\begin{array}{l}5.90^{d} \\
5.17^{b} \\
5.49^{c}\end{array}$ & $\begin{array}{l}4.94^{c} \\
4.63^{b} \\
5.33^{e} \\
\end{array}$ & $\begin{array}{l}4.42^{a} \\
5.62^{c} \\
6.56^{e}\end{array}$ & $\begin{array}{l}5.09 \\
5.14 \\
5.79 \\
\end{array}$ \\
\hline Strip cropping - mean for plot & $\begin{array}{l}\mathrm{A} \\
\mathrm{B} \\
\mathrm{C}\end{array}$ & $\begin{array}{l}4.62^{a} \\
5.55^{c} \\
6.71^{e}\end{array}$ & $\begin{array}{l}4.50^{a} \\
5.17^{d} \\
5.32^{e}\end{array}$ & $\begin{array}{l}6.25^{d} \\
4.96^{b} \\
7.51^{f}\end{array}$ & $\begin{array}{l}5.12 \\
5.22 \\
6.51\end{array}$ \\
\hline \multicolumn{2}{|l|}{$\operatorname{LSD}(\alpha=0.05)$} & 0.153 & 0.07 & 0.074 & n.s. \\
\hline \multicolumn{6}{|c|}{ Average for factors } \\
\hline Sole cropping & - & $5.52^{a}$ & 4.97 & $5.53^{a}$ & $5.34^{a}$ \\
\hline Strip cropping - mean for plot & - & $5.63^{b}$ & 4.99 & $6.24 \mathrm{~b}$ & $5.62^{b}$ \\
\hline \multicolumn{2}{|l|}{$\operatorname{LSD}(\alpha=0.05)$} & 0.05 & n.s. & 0.026 & 0.04 \\
\hline- & $\mathrm{A}$ & $5.26^{a}$ & $4.72^{a}$ & $5.33^{a}$ & $5.12^{a}$ \\
\hline- & B & $5.36^{b}$ & $4.90^{b}$ & $5.29^{a}$ & $5.18^{a}$ \\
\hline- & $\mathrm{C}$ & $6.10^{c}$ & $5.32^{c}$ & $7.03^{c}$ & $6.15^{b}$ \\
\hline \multicolumn{2}{|l|}{$\operatorname{LSD}(\alpha=0.05)$} & 0.08 & 0.04 & 0.040 & 0.27 \\
\hline Years & $\begin{array}{l}2004 \\
2005 \\
2006\end{array}$ & \multicolumn{4}{|c|}{$\begin{array}{l}5.57^{b} \\
4.98^{a} \\
5.88^{b}\end{array}$} \\
\hline \multicolumn{2}{|l|}{$\operatorname{LSD}(\alpha=0.05)$} & \multicolumn{4}{|c|}{0.37} \\
\hline
\end{tabular}

*Weed control: A - mechanical, B - mechanical-chemical, C - chemical $a, b, c, d, e, f-$ mean in columns marked with the same letter do not differ significantly

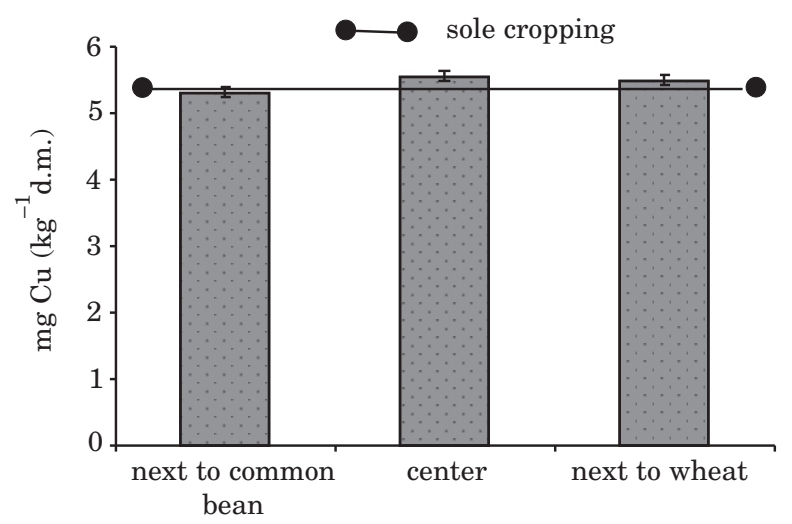

Fig. 3. The influence of adjacent row on copper content in maize 
elements in the maize in strip cropping was similar or slightly higher than in sole cropping. SkowroŃSKA and FiLIPEK (2009) report that the most intensive uptake of micronutrients, especially copper, occurs between 109 and 132 days after the sowing of maize.

Changes in the copper content in plants from each row were similar in the variants of mechanical-chemical and chemical weed control methods, but different from the variant in which only mechanical weeding was applied (Figure 4).

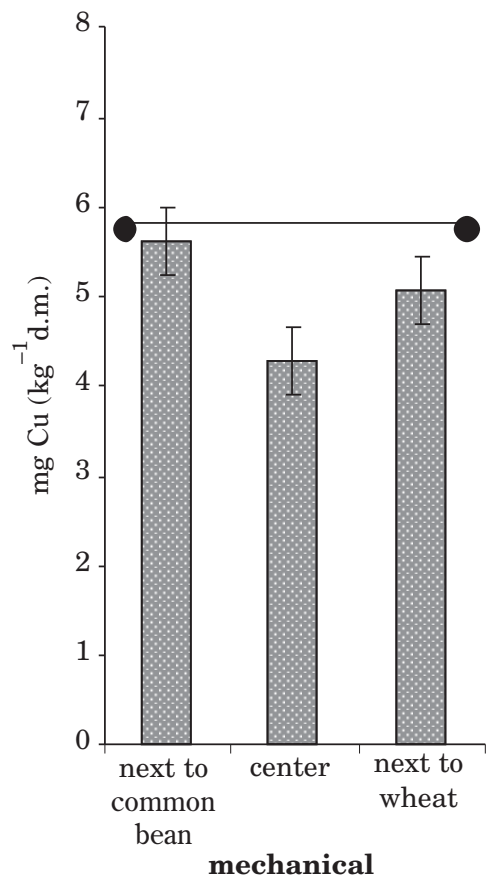

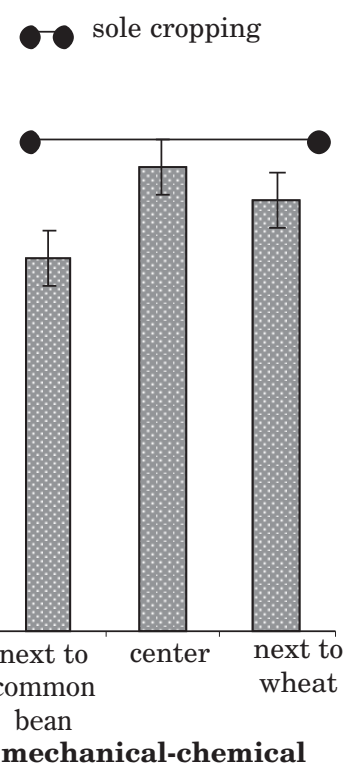

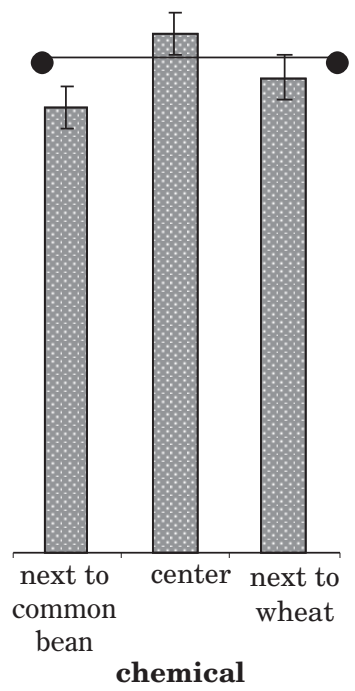

Fig. 4. The influence of adjacent row and weed control method on copper content in maize

The soil on which maize was grown on had an average content of bioavailable zinc and copper (extracted in $1 \mathrm{~mol} \mathrm{dm}^{-3} \mathrm{HCl}$ ). The low content of zinc and copper in maize supports the claim that the uptake of these elements by plants depends on their total content in soil and on other factors that affect their phytoavailability (GARCIA-MinA et al. 2004). Complex interactions take place in soil between macro- and micronutrients, and these processes are significantly influenced by the soil pH (GRzYś 2004). Moreover, research by KorzeniowsKa and StanisławsKa-GLubiak (2004) indicate that the solutions used in the analysis, i.e. $1 \mathrm{~mol} \mathrm{dm}^{-3} \mathrm{HCl}, 0.1 \mathrm{~mol} \mathrm{dm}^{-3} \mathrm{HCl}$, and DTPA, extracted significantly more zinc than a plant can take up. 
Weeds are often more efficient in the uptake of nutrients than crops, hence widespread occurrence of weeds may limit availability of elments to crops. Plants that produce less yield contain more micronutrients per unit mass produced in relation to their availability in soil than high-yielding plants. At higher yields, plants are unable to take up from the soil sufficient quantities of nutrients, which are 'diluted' in the plant biomass (CAKMAK 2004). This, however, was not confirmed in my study. The highest copper content was noticed in maize from sites where the chemical weed control method alone was used, which also favoured the production of large amounts of biomass (Table 4). On average, significantly less copper was accumulated by plants cultivated under the mechanical and mechanical-chemical weed control methods, and the differences between these methods were not significant. Also, Pearson's correlation coefficient $(r=0.556, p<0.01)$ confirms the positive relationship between the yield of maize and $\mathrm{Cu}$ content in the biomass. On average for the whole experiment, zinc content was also the highest in maize weeded chemically (Table 3 ). However, in the successive years, the impact of the weed control methods was changeable. On average for the experiment, no significant interaction was confirmed between the methods of cultivation and weed control in shaping the content of $\mathrm{Cu}$ in maize. It may be noted that under the mechanical weed control method, in contrast to the mechanical-chemical and chemical methods, the zinc content in maize was higher in strip cropping. This may have resulted from the effect of strip cropping identified and discussed elsewhere (GŁOWACKA 2007), in which weed infestation of maize was controlled mechanically and weed competition was therefore weaker. The weather conditions significantly influenced the content of zinc and copper in the maize. The lowest content of these microelements in the dry matter of maize was noted in 2005, when there was little rainfall in July and August. The highest content of zinc and copper was recorded in 2006. Copper is arrested in soil by organic matter and released during its decomposition. Soil moisture is an important factor affecting the decomposition of organic matter and, consequently, the release of copper to the soil solution and availability of this element to plants (STANISŁAWSKA-GLUBIAK, KORZENIOWSKA 2010). The effect of rainfall on the bioavailability of micronutrients and their higher content in plants is confirmed by other authors (RAJCAN, Swanton 2001, Klikocka 2011). However, there are also some contradictory reports, for example a three-year experiment carried out by KRASKA (2011), in which a higher content of trace elements $(\mathrm{Cu}, \mathrm{Zn}, \mathrm{Fe}$ and $\mathrm{Mn}$ ) was obtained in wheat grain in a year when there was less rainfall, but it was evenly distributed throughtout the entire growing season.

The intake of zinc by maize determined in this study (an average of 240 g per 1 ha) is similar to the results reported by RABIKowskA and PIsZCZ (2004). On average, significantly less zinc was accumulated by maize grown in strip cropping with spring wheat and common beans than in sole cropping (Table 5). According to Czuba (2000), the uptake of copper is $118 \mathrm{~g}$ of maize for 
Table 5

Uptake of zinc with maize yield depending on the method of cropping and weed control $\left(\mathrm{g} \mathrm{ha}^{-1}\right)$

\begin{tabular}{|c|c|c|c|c|c|}
\hline \multirow{2}{*}{ Method of cultivation } & \multirow{2}{*}{$\begin{array}{c}\text { Weed } \\
\text { control* }^{*}\end{array}$} & \multicolumn{3}{|c|}{ Years } & \multirow{2}{*}{ Average } \\
\hline & & 2004 & 2005 & 2006 & \\
\hline Sole cropping & $\begin{array}{l}\mathrm{A} \\
\mathrm{B} \\
\mathrm{C}\end{array}$ & $\begin{array}{l}310.9^{b c} \\
401.7^{d} \\
288.8^{b}\end{array}$ & $\begin{array}{l}107.9^{a} \\
143.8^{a} \\
234.2^{c}\end{array}$ & $\begin{array}{l}225.8 \\
213.2 \\
303.3\end{array}$ & $\begin{array}{l}214.9 \\
252.9 \\
275.4\end{array}$ \\
\hline Strip cropping - mean for plot & $\begin{array}{l}\text { A } \\
\text { B } \\
\text { C }\end{array}$ & $\begin{array}{l}208.2^{a} \\
239.4^{a} \\
337.8^{c}\end{array}$ & $\begin{array}{l}152.4^{b} \\
204.5^{c} \\
207.0^{c}\end{array}$ & $\begin{array}{l}245.0 \\
235.6 \\
260.5\end{array}$ & $\begin{array}{l}201.9 \\
226.5 \\
268.4\end{array}$ \\
\hline $\operatorname{LSD}(\alpha=0.05)$ & & 44.44 & 38.20 & n.s. & n.s. \\
\hline \multicolumn{6}{|c|}{ Average for factors } \\
\hline Sole cropping & - & $333.8^{b}$ & $162.0^{a}$ & 247.4 & $247.7^{b}$ \\
\hline Strip cropping - mean for plot & - & $261.8^{a}$ & $188.0^{b}$ & 247.1 & $232.2^{a}$ \\
\hline \multicolumn{2}{|l|}{$\operatorname{LSD}(\alpha=0.05)$} & 15.77 & 13.55 & n.s. & 12.79 \\
\hline- & A & $259.5^{a}$ & $130.2^{a}$ & $235.4^{a}$ & $208.4^{a}$ \\
\hline- & B & $320.6^{b}$ & $174.2^{b}$ & $224.4^{a}$ & $239.7^{b}$ \\
\hline- & $\mathrm{C}$ & $313.3^{b}$ & $220.6^{c}$ & $281.9^{b}$ & $271.9^{c}$ \\
\hline \multicolumn{2}{|l|}{$\operatorname{LSD}(\alpha=0.05)$} & 24.22 & 20.82 & 44.03 & 19.65 \\
\hline Years & $\begin{array}{l}2004 \\
2005 \\
2006\end{array}$ & \multicolumn{4}{|c|}{$\begin{array}{l}297.8^{c} \\
175.0^{a} \\
247.2^{b}\end{array}$} \\
\hline \multicolumn{2}{|l|}{$\operatorname{LSD}(\alpha=0.05)$} & \multicolumn{4}{|c|}{21.45} \\
\hline
\end{tabular}

*Weed control: A - mechanical, B - mechanical-chemical, C - chemical $a, b, c, d-$ mean in columns marked with the same letter do not differ significantly

1 ha. However, in a study conducted by RABIKowsKa and PiszCZ (2004), maize uptake was $51.6 \mathrm{~g}$ of $\mathrm{Cu}$ per $1 \mathrm{ha}$. In our study, on average for the experiment, maize took up $95.5 \mathrm{~g}$ of copper from 1 ha (Table 6), while the effect of the cultivation method on the copper uptake was negligible. The total uptake of zinc and copper was the highest when chemical weed control was used and the lowest in the case of mechanical weeding (Tables 5 and 6). This was caused by the yield volumes. The close relationship between the uptake of these micronutrients and yield is confirmed by Pearson's correlation coefficient, $r=0.945(p<0.001)$ for copper and $r=0.910(p<0.001)$ for zinc. Positive correlation was verified between the uptake and content of copper $-r=0.786(\mathrm{p}<0.001)$ and zinc $-r=0.649(p<0.001)$. Similar results were obtained by MAZUR and Sienkiewicz (2009), who report that the uptake of $\mathrm{Cu}$ and $\mathrm{Zn}$ were significantly correlated with the content of these trace elements in the biomass of maize ( $r=0.66$ for $\mathrm{Cu}$ and $r=0.65$ for $\mathrm{Zn})$. 
Table 6

Uptake of copper with maize yield depending on the method of cropping and weed control $\left(\mathrm{g} \mathrm{ha}^{-1}\right)$

\begin{tabular}{|c|c|c|c|c|c|}
\hline \multirow{2}{*}{ Method of cultivation } & \multirow{2}{*}{$\begin{array}{c}\text { Weed } \\
\text { control }^{*}\end{array}$} & \multicolumn{3}{|c|}{ Years } & \multirow{2}{*}{ Average } \\
\hline & & 2004 & 2005 & 2006 & \\
\hline Sole cropping & $\begin{array}{l}\text { A } \\
\text { B } \\
\text { C }\end{array}$ & $\begin{array}{c}121.4^{b} \\
118.1^{b b} \\
127.2^{b}\end{array}$ & $\begin{array}{l}72.1^{a b} \\
73.8^{a b} \\
99.4^{c}\end{array}$ & $\begin{array}{c}54.1 \\
93.9 \\
105.9\end{array}$ & $\begin{array}{c}82.6 \\
95.3 \\
110.8\end{array}$ \\
\hline Strip cropping - mean for plot & $\begin{array}{l}\text { A } \\
\text { B } \\
\text { C }\end{array}$ & $\begin{array}{c}87.0^{a} \\
109.9^{b} \\
140.6^{d}\end{array}$ & $\begin{array}{c}62.9^{a} \\
92.4^{b c} \\
97.88^{b c}\end{array}$ & $\begin{array}{c}72.2 \\
75.7 \\
114.3\end{array}$ & $\begin{array}{c}74.0 \\
92.7 \\
117.6\end{array}$ \\
\hline $\operatorname{LSD}(\alpha=0.05)$ & & 18.32 & 24.50 & n.s. & n.s. \\
\hline \multicolumn{6}{|c|}{ Average for factors } \\
\hline Sole cropping & - & $122.2^{b}$ & 81.8 & 84.7 & 96.2 \\
\hline Strip cropping - mean for plot & - & $112.5^{a}$ & 84.41 & 87.4 & 94.8 \\
\hline \multicolumn{2}{|l|}{$\operatorname{LSD}(\alpha=0.05)$} & 6.50 & n.s. & n.s. & n.s. \\
\hline- & A & $104.2^{a}$ & $67.5^{a}$ & $63.2^{a}$ & $78.3^{a}$ \\
\hline- & $\mathrm{B}$ & $114.0^{a}$ & $83.1^{b}$ & $84.8^{b}$ & $94.0^{b}$ \\
\hline- & $\mathrm{C}$ & $133.9^{b}$ & $98.63^{c}$ & $110.1^{c}$ & $114.2^{c}$ \\
\hline \multicolumn{2}{|l|}{$\operatorname{LSD}(\alpha=0.05)$} & 9.99 & 13.39 & 18.23 & 7.84 \\
\hline Years & $\begin{array}{l}2004 \\
2005 \\
2006\end{array}$ & \multicolumn{4}{|c|}{$\begin{array}{l}117.4^{c} \\
95.5^{b} \\
86.0^{a}\end{array}$} \\
\hline \multicolumn{2}{|l|}{$\operatorname{LSD}(\alpha=0.05)$} & \multicolumn{4}{|c|}{8.54} \\
\hline
\end{tabular}

*Weed control: A - mechanical, B - mechanical-chemical, C - chemical $a, b, c, d$ - mean in columns marked with the same letter do not differ significantly

\section{CONCLUSIONS}

1. Strip cropping of maize with common bean and spring wheat significantly increased copper content, without affecting its uptake by the maize, compared with sole cropping. Although strip cropping decreased the zinc content and uptake on average for the whole experiment, the influence of the cultivation method varied substantially from year to year.

2. The copper content in maize and the uptake of copper and zinc were the highest in the chemical weed control variant. The effect of the weed control method on the zinc content was irregular and variable between the years. 
3. The research revealed that the zinc and copper uptake by maize depended on the species of the adjacent crops. Maize grown adjacent to bean strips accumulated more zinc. A higher copper content was noted in maize grown next to wheat strips. However, more detailed research needs to be conducted in order to improve our understanding of the mechanism involved in this process.

\section{REFERENCES}

Alaalaoui-Sosse B., Genet P., Vinit-Dunand F., Toussaint M.L., Epron D., Badot P.M. 2004. Effect of copper on growth in cucumber plants (Cucumis sativus) and its relationships with carbohydrate accumulation and changes in ion contents. Plant Sci., 166: 12131218.

Alloway B.J. 2004. Zinc in soils and crop nutrition. International Zinc Association, Brussels, Belgium, 1-129.

Bilski E., Siódmiak J., Heimann H. 1997. Economic value of corn hybrids registered and grown in Poland in 1972-1996. Zesz. Prob. Post. Nauk Rol., 450: 31-54. (in Polish)

BuRCZYK P. 2003. Advantages of strip cultivation with papilionaceous intercrop plants versus possible nitrogen loss limitation. Post. Nauk Rol., 2(296): 16-21. (in Polish)

CAKMAK I. 2004. Plant nutrition research: Priorities to meet human needs for food in sustainable ways. Plant Soil, 247: 3-24.

Czuba R. 2000. Trace elements in modern systems of fertilization. Zesz. Probl. Post. Nauk Rol., 471: 161-169. (in Polish)

Francis Ch. 1986. Strip cropping corn and grain legumes: A review. Am. J. Altern. Agric., 1: 159-164.

Garcia-Mina J.M., Antolin M.C., SAnchez-Diaz M. 2004. Metal-humic complexes and plant micronutrient uptake: a study based on different plants species cultivated in diverse soil types. Plant Soil, 258: 57-68.

Ghaffarzadeh M., Garcia-Prechac F., Cruse R.M., Harbuz M.M. 1998. Fertilizer and soil nitrogen use by corn and border crops in strip intercropping system. Agron. J., 90: 758-762.

GŁOWACKA A. 2007. Effect of strip intercropping system on weed infestation in maize. Acta Agrophys., 10(3): 573-582. (in Polish)

G€OWACKA A. 2008. The effect of strip cropping on dimension and structure of maize yield cultivated for silage. Fragm. Agronom., 25(3): 52-60. (in Polish)

G€OWACKA A. 2010. Changes of nitrogen contents in soil and maize as a result of different methods of cropping and weeding control. Zesz. Probl. Post. Nauk Rol., 556: 85-91. (in Polish)

GŁowacka A., Klikocka H., Juszczak D. 2011. The influence of cropping and weed control methods of maize on magnesium and calcium content and intake. Fragm. Agronom., 28(4): 25-32. (in Polish)

GondeK K. 2010. Zinc and cadmium accumulation in maize (Zea mays L.) and the concentration of mobile forms of these metals in soil after application of farmyard manure and sewage sludge. J. Elementol., 15(4): 639-652.

Gorlach E., Mazur Z. 2002. Agrochemistry. PWN, Warszawa, 348 pp. (in Polish)

Graham R.D., Welch R.M., Saunders D.A., Ortiz-Monasterio I., Bouis H.E., Bonierbale M., DE Hann S., Burgos G., Thiele G., Liria R., Maisner C.A., Beebe S.E., Potts M.J., Kadian M., Hobbs P.R., Gupta R.K., Twomlow S. 2007. Nutritious subsistence food system. Adv. Agron., 92: 1-74. 
GRzYś E. 2004. The role and importance of micronutrients in plants' nutrition. Zesz. Probl. Post. Nauk Rol., 502: 89-99. (in Polish)

Kabata-Pendias A., Pendias H. 1999. The biogeochemistry of trace elements. PWN, Warszawa, 1-398. (in Polish)

Kala R. 2009. Statistics for the natural sciences. Wyd. UP w Poznaniu, 1-234. (in Polish)

KLIKocka H. 2011. The effect of sulphur kind and dose on content and uptake of micronutrients by potato tubers (Solanum tuberosum L.). Acta Sci. Pol., Hort. Cult., 10(2): 137-151.

Korzeniowska J., Stanisławska-Glubiak E. 2004. Effect of organic matter on the availability of zinc and others micronutrients to wheat plants. Zesz. Probl. Post. Nauk Rol., 502: 157-164. (in Polish)

Kraska P. 2011. Content of some elements in grain of spring wheat cv. Zebra depending on soil tillage systems and catch crops. J. Elem., 16(3): 407-410. DOI: 10.5601/ J.Elem.2011.16.3.06.

Li L., Sun J., Zhang F., Li X., YAng S., Rengel Z. 2001a. Wheat/maize or wheat/soybean strip intercropping I. Yield adventage and interspecific interactions of nutrients. Field Crops Res., 71: 133-137.

Li L., Sun J., Zhang F., Li X., Rengel Z., YANG S. 2001b. Wheat/maize or wheat/soybean strip intercropping II. Recovery or compensation of maize and soybean after wheat harvesting. Field Crops Res., 71: 173-181.

Mazur Z., Sienkiewicz S. 2009. Effect of urea applied with composts on concentration of Cu, $\mathrm{Zn}$ and $\mathrm{Mn}$ in corn fresh matter. J. Elementol., 14(2): 323-330.

PN-EN ISO 6869:2002. Forage - Determination of the content of calcium, copper, iron, magnesium, manganese and zinc - method by atomic absorption spectrometry. PKN Warszawa, pp. 18. (in Polish)

Rabikowska B., Piszcz U. 2004. Effect of differentiated nitrogen fertilization on utilization of copper, manganese and zinc of FYM in 4 year crop rotation. Part I. Copper. Zesz. Probl. Post. Nauk Rol., 502: 267-275. (in Polish)

RajCAN I., Swanton C.J. 2001. Understanding maize-weed competition: resource competition, light quality and the whole plant. Field Crops Res., 71: 139-150.

Salgueiro M.J., Zubillaga M., Lysionek A., Sarabia M.I., Caro R., De Paoli T., Hager A., Weill R., Boccio J. 2000. Zinc as essentials micronutrient: a review. Nutrit. Res., 20(5): 735-755.

Simic D., Sudar R., Ledencan T., Jambrovic A., Zdunic Z., Brkic I., Kovacevic V. 2009. Genetic variation of bioavailable iron and zinc in grain of a maize population. J. Cereal Sci., 50: 392-397.

Skowrońska M., Filipen T. 2009. The content and uptake of micronutrients by maize under the conditions of differentiated mineral fertilization. Zesz. Probl. Post. Nauk Rol., 541: 383389. (in Polish)

Staniszawska-Glubiak E., Konzeniowska J. 2010. Variation in micronutrients concentration in lupine, pea and maize during the vegetation period on sandy soils. Pol. J. Agron., 2: 64-66.

Szlegel-Zawadzka M. 2001. Zinc - Heath and therapy-related aspects. Causes and signs of zinc deficit. In: Conference proceedings, Minerals in health and illness. Zinc. Olsztyn, 14 March 2001, 5-23 ss. (in Polish)

Szymańska G., Sulewska H., Panasiewicz K. 2009. The content of microelements in grain of six maize cultivars depending on the harvest date. Zesz. Probl. Post. Nauk Rol., 541: 433-439.

Szyszkowska A., Sowiśski J., WierzBicki H. 2007. Changes in the chemical composition of maize cobs depending on the cultivar, effective temperature sum and farm type. Acta Sci. Pol., Agricultura, 6(1): 13-22.

Zhang F., Li L. 2003. Using competitive and facilitative interactions in intercropping systems enhances crop productivity and nutrient-use efficiency. Plant Soil, 248: 305-312. 